\title{
木質バイオマス地域熱供給システムの温室効果ガス排出削減効果 岩手県紫波町を対象として*1
}

\author{
加用千裕*2，大慈彌亮太*3，岩岡正博*2，安田幸治*4
}

\section{Greenhouse Gas Emission Reductions in a District Heating and Cooling System by Using Woody Biomass A study in Shiwa, Iwate Prefecture*1}

\author{
Chihiro KAYO*2, Ryota OJIMI*3, \\ Masahiro IwAOKA*2 and Koji YASUDA*4
}

\begin{abstract}
A life cycle assessment of greenhouse gas (GHG: $\mathrm{CO}_{2}, \mathrm{CH}_{4}, \mathrm{~N}_{2} \mathrm{O}$ ) emissions for a district heating and cooling (DHC) system using woody biomass was conducted, and reductions in emissions from substitution of fossil fuels with woody biomass were analyzed in Shiwa, Iwate Prefecture. From the process of log production to heating, the life cycle GHG emissions of the $\mathrm{DHC}$ system were $70.8 \mathrm{~kg}-\mathrm{CO}_{2 \text {-eq }} / \mathrm{GJ}$ heat. Of these emissions, the majority (92\%) originated from the heating process. Substitution of liquefied petroleum gas (LPG) with wood chips resulted in a reduction of GHG emissions of $92.4 \mathrm{~kg}$ - $\mathrm{CO}_{2 \text {-eq }} /$ GJ-heat. With this substitution taken into account, the net GHG emissions of the DHC system were $21.6 \mathrm{~kg}-\mathrm{CO}_{2-\mathrm{eq}} / \mathrm{GJ}$-heat, which indicated that the DHC system had the potential to reduce GHG emissions. The GHG emission reductions generated by the DHC system would not be obtained if the heat usage efficiency were reduced from the current $29 \%$ to less than $23 \%$. Conversely, if the heat usage efficiency were improved to $75 \%$, reductions in GHG emissions corresponding three times the current levels could be obtained. The GHG emission reductions could also increase if kerosene or heavy oil were used as a substitute for the currently used LPG. However, compared to the significant impact of heat usage efficiency, the substitution of fossil fuels had a relatively minor effect on the reduction of GHG emissions.
\end{abstract}

Keywords : woody biomass, DHC system, LCA, greenhouse gas, fossil fuel substitution.

岩手県紫波町における木質バイオマス地域熱供給システムのライフサイクル温室効果ガス ( $\mathrm{GHG}: \mathrm{CO}_{2}, \mathrm{CH}_{4}, \mathrm{~N}_{2} \mathrm{O}$ ) 排出量および化石燃料代替に伴う $\mathrm{GHG}$ 排出削減量を評価した。丸太生 産過程から熱供給過程までのライフサイクル $\mathrm{GHG}$ 排出量は70.8 kg-CO $\mathrm{CO}_{2-\mathrm{eq}} / \mathrm{GJ}$-heat となり, 熱 供給過程からの排出量が全体の $92 \%$ を占めた。一方, 被代替過程における液化石油ガス (LPG) 代替によって92.4 kg-CO $\mathrm{CO}_{2-\mathrm{eq}} / \mathrm{GJ}$-heatの GHG 排出削減量が得られ，これを考慮した正味の GHG

*1 Received February 19, 2016; accepted March 18, 2016.

*2 東京農工大学大学院農学研究院 Graduate School of Agriculture, Tokyo University of Agriculture and Technology, Fuchu 183-8509, Japan

*3 東京農工大学農学部 Faculty of Agriculture, Tokyo University of Agriculture and Technology, Fuchu 183-8509, Japan

*4 林野庁林政部 Forest Policy Planning Department, Forestry Agency, Tokyo 100-8952, Japan

Corresponding author: C. Kayo(kayoc@cc.tuat.ac.jp) 
排出量は-21.6 kg- $\mathrm{CO}_{2-\mathrm{eq}} / \mathrm{GJ}$-heat となり，化石燃料代替に伴う GHG 排出削減効果が期待でき ることが分かった。また，現状の熱利用効率 $29 \%$ が $23 \%$ まで低下すると GHG 排出削減効果は得 られなくなるが，75\% まで改善することができれば現状の 3 倍の GHG 排出削減効果が得られる 可能性がある。

\section{1. 緒言}

木材は炭素貯蔵効果, 材料代替効果, エネルギー 代替効果を通して地球温暖化の緩和に貢献すると認 識されている ${ }^{1)}$ 。特に，エネルギー代替効果は木質 バイオマスをエネルギー利用することにより，温室 効果ガス（GHG）の主な発生源である化石燃料を 直接的に代替し, 化石燃料消費由来の GHG 排出量 を削減するものであり，国内外において関心が高ま っている。木質バイオマスのエネルギー利用形態は 複数あり, 電力, 熱供給, 自動車燃料が代表例とし て挙げられる。2012年 7 月から開始された再生可能 エネルギー固定価格買取制度では，木質バイオマス による発電が対象とされているが，熱供給や自動車 燃料は対象外となっている ${ }^{2)}$ 。しかし，発電による エネルギー利用効率が $20 \%$ 前後であるのに対し， 熱供給によるエネルギー利用効率は75\% 程度が見 込まれるとする報告3) もあり，十分な熱需要がある 地域では熱供給が有望なエネルギー利用形態になり 得ると考えられる。

特に近年，木質バイオマスによる地域熱供給 (DHC : district heating and cooling) システムが 注目されている。地域熱供給システムとは, 1 カ所 または数力所の熱供給施設から複数の建物・施設に 配管を通して, 温水, 冷水, 蒸気を送り, 給湯, 暖 房, 冷房等を行うものである。スウェーデンやオー ストリアを中心に欧州諸国で普及が進んでいるが, 日本においても北海道下川町, 岩手県紫波町, 山形 県小国町, 山形県最上町, 滋賀県高島市, 山口県下 関市等の先進事例 ${ }^{4)}$ がある。地域内で生産される木 質バイオマスをエネルギー源とする地域熱供給がで きれば，その地域でのエネルギー自給率が高まり， さらに GHG 排出削隇効果も期待できる。

木質バイオマスのエネルギー利用による GHG 排 出削減効果を定量的に評価する方法の 1 つにライフ サイクルアセスメント (LCA) がある。LCA とは, 対象とする製品やサービスを生み出す資源の採取か ら製品の使用・廃棄段階まで，ライフサイクル全体 を通して資源消費量や環境負荷排出量を計量し，そ の環境への影響を評価する手法である。LCA 手法 を用いて木質バイオマスエネルギーの GHG 排出量 や排出削減効果を検討した先行研究としては, 発電
を対象とした研究5), 木質ペレットを対象とした研 究6,7), 自動車燃料を対象とした研究8, 9), 電熱併給 を対象とした研究 ${ }^{10}$, 複数のエネルギー利用形態を 比較評価した研究11-14) 等が報告されている。しかし, 日本国内に打いて複数の建物・施設へ給湯, 暖房, 冷房等を供給する木質バイオマス地域熱供給システ ムを対象としたLCA に関する先行研究はこれまで 報告されて抢らず，ライフサイクルを通した $\mathrm{GHG}$ 排出量や化石燃料との代替による GHG 排出削減効 果はまだ明らかになっていない。

そこで，本研究では，日本に打ける先進事例の 1 つである岩手県紫波町の木質バイオマス地域熱供給 システムを対象に, LCA 手法によってライフサイ クル $\mathrm{GHG}$ 排出量を評価し, さらに, 化石燃料との 代替に伴う GHG 排出削減効果を明らかにすること を目的とする。

\section{2. 方法}

\section{1 対象とした地域および熱供給システムの概要}

対象地域である紫波町は岩手県のほぼ中央, 盛岡 市と花巻市の中間に位置し, 北上川が中央を流れ, 東は北上高地, 西は奥羽山脈までの総面積 238.98 $\mathrm{km}^{2}$ (このうち $57.8 \%$ が森林)，人口 33696 人（2015 年 3 月 31 日現在) ${ }^{15)}$ の町である。紫波町内の JR 東 北本線紫波中央駅前にオガール地区と呼ばれる町有 地10.7 ha があり，その概要を Fig. 1 に示した。才 ガール地区は町役場庁舎, 一般住宅（オガールタウ ン), ビジネスホテル・体育館・飲食店を中心とす る商業施設（オガールベース），図書館・産直市場

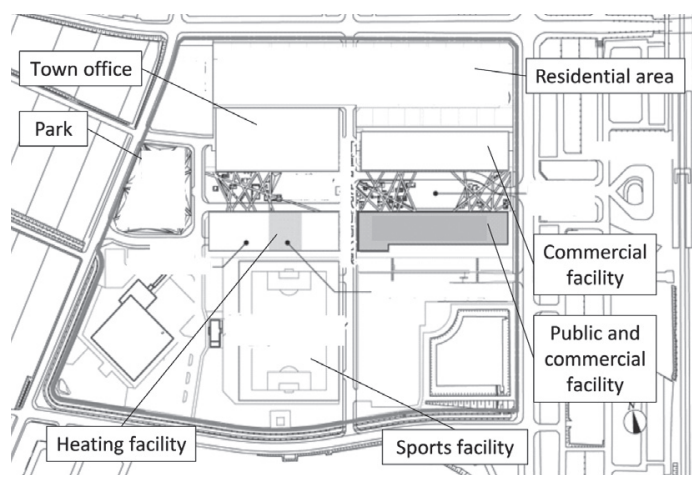

Fig. 1. Overview of the Ogal area. ${ }^{15)}$ 
を中心とする公共·商業複合施設(オガールプラザ), スポーツ施設, 公園, 木質バイオマスによる熱供給 施設（エネルギーステーション）等で構成されてい る。熱供給施設では, 紫波町内産の木材を燃料とす る木質チップボイラーを熱源として, 町役場庁舎, 一般住宅，商業施設に給湯・暖房・冷房用の熱を供 給している。燃料の木質チップの生産・運搬は A 社が行い, 熱供給施設の管理・運営は B 社が行っ ている。この地域熱供給事業は2014年 7 月から開始 されている。

\section{2 評価対象範囲}

評価対象とした木質バイオマス熱供給システムの ライフサイクル（システム境界）は丸太生産，丸太 輸送, チップ生産, チップ輸送, 熱供給の各過程と し, Fig. 2 およびFig. 3 に示した。焼却灰は周辺農 家において土壤改良材として再利用されているた め, 燒却灰処理過程は検討しなかった。また，本研 究対象の熱供給施設には, 補助・非常用の液化石油 ガス（LPG）ボイラーが設置されており，木質チッ プボイラーと同地区・同規模への熱供給が可能であ る。そこで, 木質チップボイラーによる熱供給によ って LPG ボイラーを代替することを想定し, 被代 替過程として資源採取, 資源輸送, LPG 生産, LPG 輸送，LPG 燃焼を対象とした。なお，熱供給 システムに使用される設備や機器の製造・輸送・補 修・廃棄等の各過程は評価対象に含めなかった。

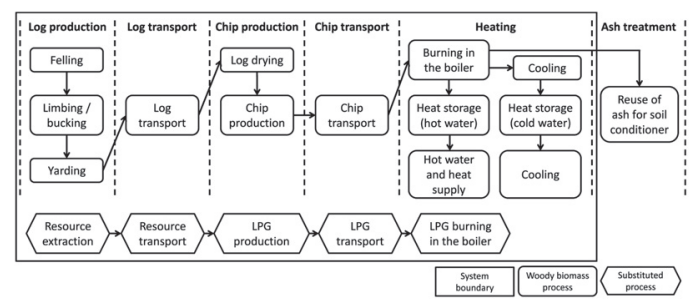

Fig. 2. Life cycle process (system boundary) of the district heating and cooling (DHC) system by using woody biomass.

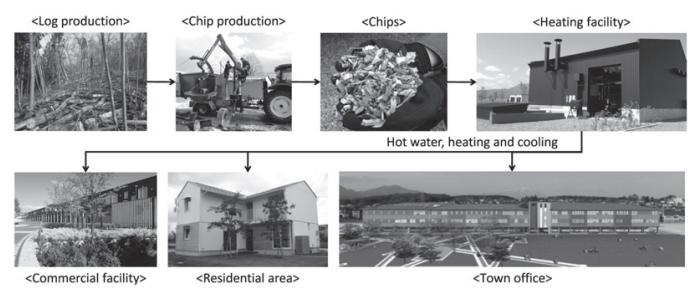

Fig. 3. Main steps from the log production process to the heating process. ${ }^{16)}$

\section{3 ライフサイクル GHG 排出量・削減量の評価}

ライフサイクル GHG 排出量・削減量の評価にお いて, 機能単位は熱供給量 $1 \mathrm{GJ}$ 当たりの排出量・ 削減量 $\left(\mathrm{kg}-\mathrm{CO}_{2 \text {-eq }} / \mathrm{GJ}\right.$-heat $)$ とした。フォアグラ ウンドデータとして収集した材料・燃料の消費量 · 代替量を Table 1 に示した。丸太生産過程は岩岡・ 一二三の先行研究 ${ }^{19)}$ を参照し, 丸太輸送, チップ 生産，チップ輸送過程は $\mathrm{A}$ 社への聞き取り調查を 行い, 熱供給過程は B 社への聞き取り調查を実施し, 各種デー夕を収集した。バックグラウンドデータと して用いた GHG 排出量原単位は MiLCA データべ ース ${ }^{21)}$ から引用し, Table 2 に示した。ここで, $\mathrm{GHG}$ 排出は化石燃料消費由来の $\mathrm{CO}_{2}, \mathrm{CH}_{4}, \mathrm{~N}_{2} \mathrm{O}$ を 評価対象とした。木質チップ由来の $\mathrm{CO}_{2}$ 排出は木材 伐採後の植栽による次世代更新を前提とし, カーボ ンニュートラルの考え方を適用して評価対象外とし たが，木質チップ由来の $\mathrm{CH}_{4}$ と $\mathrm{N}_{2} \mathrm{O}$ の排出は ISO の規定22)に従い評価対象に含めることとした。各 GHG は地球温暖化係数 100 年值 $\left(\mathrm{GWP}_{100}\right) \quad\left(\mathrm{CO}_{2}: 1\right.$, $\left.\mathrm{CH}_{4}: 34, \mathrm{~N}_{2} \mathrm{O}: 298\right)^{23)}$ を用いて $\mathrm{CO}_{2}$ 換算 $\left(\mathrm{kg}-\mathrm{CO}_{2-\mathrm{eq}}\right)$ で示した。次項以降はライフサイクル過程ごとに評 価方法を詳述する。

2.3.1 丸太生産過程

原料の丸太は紫波町内で伐採された間伐材 (スギ) および松食虫被害木（アカマツ）である。間伐材の 搬出・受入等の業務を担う $\mathrm{A}$ 社への聞き取り調查 により, 丸太生産方法は短幹集材による間伐であり, 伐木・造材工程はチェーンソーを使用し, 集材工程 は林内作業車を使用していることが確認された。そ のため,これらの工程におけるチェーンソーの燃料 (ガソリン・潤滑油) および林内作業車の燃料 (軽油) の消費を対象とし, 熱供給量当たりの丸太生産量 $\left(\mathrm{m}^{3} / \mathrm{GJ}\right.$-heat) (Table 1) に各燃料消費量 $\left(\mathrm{L} / \mathrm{m}^{3}\right)$ （Table 1）および各燃料消費に伴う GHG 排出量原 単位 $\left(\mathrm{kg}-\mathrm{CO}_{2 \text {-eq }} / \mathrm{L}\right.$ ) (Table 2) を乗じることにより, 丸太生産過程の $\mathrm{GHG}$ 排出量 ( $\mathrm{kg}-\mathrm{CO}_{2-\mathrm{eq}} / \mathrm{GJ}$-heat) を算定した。なお，各燃料消費量は岩岡・二二三の 先行研究 ${ }^{19)} に$ において実施した木材生産作業に関わ る全国規模のアンケート調査の結果から, 本研究対 象の丸太生産と同様のチェーンソーおよび林内作業 車の数值を引用した。

\subsection{2 丸太輸送過程}

熱供給量当たりの丸太生産量 $\left(\mathrm{m}^{3} / \mathrm{GJ}\right.$-heat (Table 1) に丸太の容積密度 $\left(\mathrm{t} / \mathrm{m}^{3}\right)$ （Table 1$)$, 丸太生産現場からチップ生産現場までの輸送距離 $(\mathrm{km})$ (Table 1)，2トントラックの輸送による GHG 排出量原単位 $\left(\mathrm{kg}-\mathrm{CO}_{2-\mathrm{eq}} /(\mathrm{t} \cdot \mathrm{km})\right)$ (Table 2$)$ 
Table 1. Material and energy used and substituted for each process.

\begin{tabular}{|c|c|c|c|c|}
\hline \multicolumn{2}{|r|}{ Life cycle process } & Unit & Value & Note \\
\hline $\begin{array}{l}\text { Log produc- } \\
\text { tion process }\end{array}$ & $\begin{array}{l}\text { Log production volume } \\
\text { Moisture content of } \operatorname{logs}^{17)} \\
\text { Density of logs }{ }^{17,18)} \\
\text { Gasoline consumption by chain } \\
\text { saw }{ }^{19)} \\
\text { Lubricant consumption by } \\
\text { chain saw } \text { Ligh }^{19} \\
\text { tractor }^{19} \text { consumption by forest } \\
\text { tract }\end{array}$ & $\begin{array}{l}\mathrm{m}^{3}-\log / \mathrm{GJ}-\text { heat } \\
\% \\
\mathrm{t} / \mathrm{m}^{3} \\
\mathrm{~L} / \mathrm{m}^{3}-\log \\
\mathrm{L} / \mathrm{m}^{3}-\log \\
\mathrm{L} / \mathrm{m}^{3}-\log \end{array}$ & $\begin{array}{r}0.3 \\
50 \\
0.7 \\
1.00 \\
0.60 \\
1.00\end{array}$ & $\begin{array}{l}\text { Chip production volume from logs : } 3 \mathrm{~m}^{3} \\
\text {-chip/ } \mathrm{m}^{3}-\log ^{*} \\
\text { Wet basis } \\
\text { The weighted average of Japanese cedar } \\
\text { is } 70 \% \text { and Japanese red pine is } 30 \% \\
\text { For felling, limbing and bucking } \\
\text { For felling, limbing and bucking } \\
\text { For yarding }\end{array}$ \\
\hline $\begin{array}{l}\text { Log trans- } \\
\text { port process }\end{array}$ & Transport distance of logs* & $\mathrm{km}$ & 10 & $\begin{array}{l}\text { From the log production site to the chip } \\
\text { production site, } 2 \text { ton truck }\end{array}$ \\
\hline $\begin{array}{l}\text { Chip produc- } \\
\text { tion process }\end{array}$ & $\begin{array}{l}\text { Chip production volume* } \\
\text { Moisture content of chips** } \\
\text { Density of chips** } \\
\text { Light oil consumption by } \\
\text { chipper* }\end{array}$ & $\begin{array}{l}\mathrm{m}^{3} \text {-chip/GJ-heat } \\
\% \\
\mathrm{t} / \mathrm{m}^{3} \\
\mathrm{~L} / \mathrm{m}^{3} \text {-chip }\end{array}$ & $\begin{array}{r}1.0 \\
30 \\
0.25 \\
0.5\end{array}$ & $\begin{array}{l}\text { Chip production volume from logs: } 3 \mathrm{~m}^{3} \\
\text {-chip/m } \mathrm{m}^{3}-\log ^{*} \\
\text { Wet basis }\end{array}$ \\
\hline $\begin{array}{l}\text { Chip tr } \\
\text { port pr }\end{array}$ & Transport distance of chips* & $\mathrm{km}$ & 7 & $\begin{array}{l}\text { From the chip production site to the heat } \\
\text { supply site, } 1.5 \text { ton truck }\end{array}$ \\
\hline $\begin{array}{l}\text { Heating } \\
\text { process }\end{array}$ & $\begin{array}{l}\text { Chip consumption }{ }^{* * *} \\
\\
\text { Kerosene consumption }{ }^{* * *} \\
\text { LPG consumption }{ }^{* * *} \\
\text { Electricity consumption*** } \\
\text { Industrial water consumption }{ }^{* * *}\end{array}$ & $\begin{array}{l}\mathrm{m}^{3} / \mathrm{GJ} \text {-heat } \\
\mathrm{L} / \mathrm{GJ} \text {-heat } \\
\mathrm{m}^{3} / \mathrm{GJ} \text {-heat } \\
\mathrm{kWh} \text {-GJ-heat } \\
\mathrm{m}^{3} / \mathrm{GJ} \text {-heat }\end{array}$ & \begin{tabular}{r|}
1.0 \\
1.7 \\
1.5 \\
80.1 \\
0.2 \\
\end{tabular} & $\begin{array}{l}\text { Net calorific value : } 13.1(\mathrm{GJ} / \mathrm{t})^{* *} \text {, heat } \\
\text { usage efficiency : } 29 \%(0.29)^{* * *} \\
\text { Net calorific value : } 0.034(\mathrm{GJ} / \mathrm{L})^{20)} \\
\text { Net calorific value : } 0.091(\mathrm{GJ} / \mathrm{m} 3)^{20)}\end{array}$ \\
\hline $\begin{array}{l}\text { Ash treat- } \\
\text { ment process }\end{array}$ & Incinerated ash generation ${ }^{* *}$ & $\mathrm{~m}^{3} / \mathrm{GJ}$-heat & 0.02 & $2 \%$ of chip consumption ${ }^{* *}$ \\
\hline $\begin{array}{l}\text { Substituted } \\
\text { process }\end{array}$ & LPG substitution with chips & $\mathrm{m}^{3} / \mathrm{GJ}$-heat & 12.6 & $\begin{array}{l}\text { Net calorific value : } 0.091\left(\mathrm{GJ} / \mathrm{m}^{3}\right)^{20)} \text {, heat } \\
\text { usage efficiency : } 84 \%(0.84)^{* * * *}\end{array}$ \\
\hline
\end{tabular}

* An interview survey with A corporation

** An interview survey with B corporation

*** Numeric data obtained from B corporation

Table 2. Greenhouse gas (GHG) emission intensities. ${ }^{21)}$

\begin{tabular}{|c|c|c|c|c|c|c|}
\hline & Unit & $\mathrm{CO}^{2}$ & $\mathrm{CH}_{4}$ & $\mathrm{~N}_{2} \mathrm{O}$ & $\begin{array}{l}\text { GHG } \\
\text { total }\end{array}$ & Scope of assessment \\
\hline Chip combustion & $\mathrm{kg}-\mathrm{CO}_{2-\mathrm{eq}} / \mathrm{m}^{3}$ & - & 0.003 & 0.000 & 0.003 & Chip combustion (for $\mathrm{CH}_{4}$ and $\mathrm{N}_{2} \mathrm{O}$, \\
\hline Transport by 2 ton truck & $\mathrm{kg}-\mathrm{CO}_{2-\mathrm{eq}} / \mathrm{t} \cdot \mathrm{km}$ & 0.219 & 0.008 & 0.001 & 0.228 & Resource extraction light oil \\
\hline Transport by 1.5 ton truck & $\mathrm{kg}-\mathrm{CO}_{2-\mathrm{eq}} / \mathrm{t} \cdot \mathrm{km}$ & 0.226 & 0.009 & 0.001 & 0.236 & Resource extraction light oil \\
\hline Gasoline consumption & $\mathrm{kg}-\mathrm{CO}_{2-\mathrm{eq}} / \mathrm{L}$ & 2.720 & 0.106 & 0.014 & 2.839 & $\begin{array}{l}\text { production } \text { lignt ofl combustion } \\
\text { production } \sim \text { gasoline combustion }\end{array}$ \\
\hline Lubricant consumption & $\mathrm{kg}-\mathrm{CO}_{2-\mathrm{eq}} / \mathrm{L}$ & 3.510 & 0.132 & 0.023 & 3.665 & Resource extraction lubricant \\
\hline Light oil consumption & $\mathrm{kg}-\mathrm{CO}_{2-\mathrm{eq}} / \mathrm{L}$ & 2.821 & 0.107 & 0.014 & 2.942 & Resource extraction light oil \\
\hline Kerosene consumption & $\mathrm{kg}-\mathrm{CO}_{2-\mathrm{eq}} / \mathrm{L}$ & 2.672 & 0.103 & 0.013 & 2.788 & Resource extraction kerosene \\
\hline LPG consumption & $\mathrm{kg}-\mathrm{CO}_{2-\mathrm{eq}} / \mathrm{m}^{3}$ & 7.017 & 0.291 & 0.038 & 7.346 & Resource extraction LPG produc- \\
\hline Heavy oil consumption & $\mathrm{kg}-\mathrm{CO}_{2-\mathrm{eq}} / \mathrm{L}$ & 2.989 & 0.114 & 0.015 & 3.118 & Resource extraction $\sim$ heavy oil \\
\hline Electricity consumption & $\mathrm{kg}-\mathrm{CO}_{2-\mathrm{eq}} / \mathrm{kWh}$ & 0.583 & 0.006 & 0.019 & 0.609 & Resource extraction electricity \\
\hline Industrial water consumption & $\mathrm{kg}-\mathrm{CO}_{2-\mathrm{eq}} / \mathrm{m}^{3}$ & 0.129 & 0.002 & 0.003 & 0.134 & $\begin{array}{l}\text { Resource extraction } \sim \text { industrial } \\
\text { water supply }\end{array}$ \\
\hline
\end{tabular}

および 2 （トラック往復分）を乗じて，丸太輸送過 程の $\mathrm{GHG}$ 排出量 $\left(\mathrm{kg}-\mathrm{CO}_{2-\mathrm{eq}} / \mathrm{GJ}\right.$-heat)を算出した。 なお, 丸太の容積密度は湿量基準 (乾量基準) の含
水率 $50 \%(100 \%)^{17)}$ および全乾密度 $0.36 \mathrm{t} / \mathrm{m}^{3}$ を用い て求めた。ここで, 全乾密度は, チップの樹種比率 がスギ70\%，アカマツ $30 \%$ であることから，これら 
の全乾密度 ${ }^{18)}$ を加重平均して求めた。

2.3.3 チップ生産過程

丸太乾燥工程㧍よびチップ生産工程を対象とした。 ただし，A社への聞き取り調查により，丸太乾燥 工程では天然乾燥を行っていることが確認されたた め, 本工程の燃料消費および $\mathrm{GHG}$ 排出はゼロと想 定した。チップ生産工程は熱供給量当たりのチップ 生産量（ $\mathrm{m}^{3} / \mathrm{GJ}$-heat）（Table 1) にチッパーの燃 料（軽油）消費量 $\left(\mathrm{L} / \mathrm{m}^{3}\right)$ （Table 1$)$, 軽油消費に 伴う GHG 排出量原単位 $\left(\mathrm{kg}-\mathrm{CO}_{2 \text {-eq }} / \mathrm{L}\right)$ (Table 2) を乗じることにより， GHG 排出量 $\left(\mathrm{kg}-\mathrm{CO}_{2-\mathrm{eq}} / \mathrm{GJ}\right.$ heat）を計算した。

2.3.4 チップ輸送過程

熱供給量当たりのチップ生産量 $\left(\mathrm{m}^{3} / \mathrm{GJ}\right.$-heat $)$ (Table 1) にチップの容積密度 $\left(\mathrm{t} / \mathrm{m}^{3}\right)$ （Table 1$)$, チップ生産現場から熱供給施設までの輸送距離 $(\mathrm{km})$ (Table 1)，1.5トントラックの輸送による GHG 排出量原単位 $\left(\mathrm{kg}-\mathrm{CO}_{2 \text {-eq }} /(\mathrm{t} \cdot \mathrm{km})\right)$ (Table 2$)$ および 2 (トラック往復分) を乗じることにより， チップ輸送過程の $\mathrm{GHG}$ 排出量 $\left(\mathrm{kg}-\mathrm{CO}_{2 \text {-eq }} / \mathrm{GJ}\right.$ heat）を求めた。

\subsection{5 熱供給過程}

熱供給システムにおける主要機器は木質チップボ イラー, 吸収式冷凍機, 温水蓄熱夕ンク, 冷水蓄熱 タンク, 冷水チラー, LPG ボイラーである。木質 チップボイラーでは, 炉内に木質チップを取り入れ て燃燒させ，燃焼ガスと水を熱交換し，約 $80^{\circ} \mathrm{C}$ の温 水を作り出す。温水の一部は温水蓄熱夕ンクに送ら れ，各建物・施設へ給湯・暖房用に送水される。も う一部は吸収式冷凍機により約 $7{ }^{\circ} \mathrm{C}$ の冷水となり, 冷水蓄熱タンクから各建物・施設へ冷房用に送水さ れる。また, 冷水チラーは冷水蓄熱タンクの補助, LPG ボイラーは木質チップボイラーの補助㧍よび
非常時対応のために使用されている。

2014年 9 月～2015年 8 月の 1 年間におけるエネル ギー収支の数值デー夕を $\mathrm{B}$ 社から得て, Table 3 に 示した。なお，この数值データにおいて, エネルギ 一産出量は各建物・施設への熱供給量実測值から, エネルギー投入量は各燃料の購入伝票から算出され たものである。熱供給の直接的なエネルギー投入は 木質チップと LPG である。なお, 木質チップボイ ラーの着火のために灯油が使用され, 冷水チラーの 運転, 各建物・施設への送水, 熱供給システム制御 等のために電力が使われているが，熱源としては用 いられていない。エネルギー産出はオガール地区内 の町役場庁舎, 一般住宅, 商業施設への給湯・暖房· 冷房熱である。エネルギー産出量（Table 3 におけ る Outputの Town office, Residential area, Commercial facility の合計值) をエネルギー投入量 (Table 3 における Input の Chips と LPG の合計值) で除した熱利用効率は $29 \%$ となった。2015年 6 月 から町役場庁舎への熱供給が本格的に開始されたこ とや，2015年10月現在において一般住宅への熱供給 が 3 戸に留まっていること等から，まだ安定的な熱 需要が確保されておらず, 熱損失が大きくなったと 考えられる。

熱供給過程における $\mathrm{GHG}$ 排出量 $\left(\mathrm{kg}-\mathrm{CO}_{2-\mathrm{eq}} / \mathrm{GJ}\right.$ heat）は熱供給量当たりのチップ消費量 $\left(\mathrm{m}^{3} / \mathrm{GJ}\right.$ heat）（Table 1）にチップの燃焼に伴う GHG 排出 量原単位 $\left(\mathrm{kg}-\mathrm{CO}_{2 \text {-eq }} / \mathrm{m}^{3}\right)$ (Table 2$)$ を乗じ, また, LPG $\left(\mathrm{m}^{3} / \mathrm{GJ}\right.$-heat) ・灯油 ( $\mathrm{L} / \mathrm{GJ}$-heat) • 電力 $(\mathrm{kWh} /$ GJ-heat) - 工業用水 $\left(\mathrm{m}^{3} / \mathrm{GJ}\right.$-heat $)$ の消費量 (Table 1) にそれらの消費に伴う GHG 排出量原単 位 ( $\mathrm{LPG}: \mathrm{kg}-\mathrm{CO}_{2 \text {-eq }} / \mathrm{m}^{3}$, 灯油: $\mathrm{kg}-\mathrm{CO}_{2-\mathrm{eq}} / \mathrm{L}$, 電力: $\mathrm{kg}-\mathrm{CO}_{2 \text {-eq }} / \mathrm{kWh}$, 工業用水: $\mathrm{kg}-\mathrm{CO}_{2 \text {-eq }} / \mathrm{m}^{3}$ ) (Table 2) を各々乗じ, それらを合計することによって求めた。

Table 3. Annual energy balance of the heating process.

\begin{tabular}{|c|c|c|c|c|c|}
\hline & & \multicolumn{2}{|c|}{ Unit } & \multicolumn{2}{|c|}{ Value } \\
\hline \multirow{3}{*}{ Output (heat) } & Town office & \multicolumn{2}{|l|}{ GJ } & \multicolumn{2}{|r|}{258.54} \\
\hline & Residential area & \multicolumn{2}{|l|}{ GJ } & \multicolumn{2}{|r|}{30.939} \\
\hline & Commercial facility & \multicolumn{2}{|l|}{ GJ } & \multicolumn{2}{|r|}{1275.7} \\
\hline \multirow{4}{*}{ Input } & Chips (heat source) & GJ* & $\mathrm{m}^{3}$ & $5.3 \times 10^{3}$ & 1603.32 \\
\hline & LPG (heat source) & $\mathrm{GJ}^{* *}$ & $\mathrm{~m}^{3}$ & $2.2 \times 10^{2}$ & 2382.2 \\
\hline & Kerosene & \multicolumn{2}{|l|}{$\mathrm{L}$} & \multicolumn{2}{|r|}{2593} \\
\hline & Electricity & \multicolumn{2}{|l|}{$\mathrm{kWh}$} & \multicolumn{2}{|r|}{125375} \\
\hline
\end{tabular}

* The value was calculated by multiplying input value of chips $\left(\mathrm{m}^{3}\right)$ by density of chips $\left(0.25 \mathrm{t} / \mathrm{m}^{3}\right)$ (Table 1$)$, and by net calorific value of chips $(13.1 \mathrm{GJ} / \mathrm{t})$ (30\% moisture content) (Table 1$)$.

** The value was calculated by multiplying input value of LPG $\left(\mathrm{m}^{3}\right)$ by net calorific value of LPG $\left(0.091 \mathrm{GJ} / \mathrm{m}^{3}\right)$ (Table 1$)$. 
なお, チップの燃焼に伴う GHG 排出量原単位は, 2.3 に打いて記述したと扔り, ISOの規定22)に従い, $\mathrm{CH}_{4}$ と $\mathrm{N}_{2} \mathrm{O}$ は含み， $\mathrm{CO}_{2}$ は含まないこととした。

2.3.6 被代替過程

木質チップの化石燃料代替に伴う GHG 排出削減 量を検討した。2.2において述べたとおり，LPGを 被代替対象の化石燃料とした。熱供給量当たりの木 質チップ消費量を式（1）により求め, 低位発熱量 換算での木質チップによる LPG 代替量を式（2）に より求めた。

$$
\begin{aligned}
\mathrm{WC} & =\frac{\mathrm{AWC}}{\mathrm{AHS}} \\
\mathrm{SL} & =\frac{\mathrm{WC} \times \mathrm{DW} \times \mathrm{CW} \times \mathrm{EW}}{\mathrm{CL} \times \mathrm{EL}}
\end{aligned}
$$

ここで, WC $\left(\mathrm{m}^{3} / \mathrm{GJ}\right.$-heat）は熱供給量当たりのチ ップ消費量, $\mathrm{AWC}\left(\mathrm{m}^{3}\right)$ は熱供給システムにおけ る 1 年間の木質チップ消費量, AHS（GJ-heat）は 熱供給システムにおける 1 年間の熱供給量を示し,

Table 3 を用いて算定した。その結果, 熱供給量当 たりのチップ消費量（WC）は $1.0 \mathrm{~m}^{3} / \mathrm{GJ}$-heat とな った。SL（ $\mathrm{m}^{3} / \mathrm{GJ}$-heat）は熱供給量当たりの LPG 代替量, $\mathrm{DW}\left(\mathrm{t} / \mathrm{m}^{3}\right)$ はチップの容積密度（湿量基 準の含水率30\%), CW (GJ-chip/t）はチップの低 位発熱量, EW はチップの熱利用効率, $\mathrm{CL}(\mathrm{GJ}$ $\left.\mathrm{lpg} / \mathrm{m}^{3}\right)$ は LPGの低位発熱量, EL は LPGの熱利 用効率を示し, 各数值は Table 1 に示した。なお, チップの低位発熱量 $(\mathrm{CW})$ は, スギの高位発熱量 (全 乾時) $20.9 \mathrm{GJ} / \mathrm{t} \quad(4985 \mathrm{cal} / \mathrm{g})^{24)}$ およびアカマッの高 位発熱量 (全乾時) $21.7 \mathrm{GJ} / \mathrm{t}(5175 \mathrm{cal} / \mathrm{g})^{24)}$ をチッ プの樹種比率（スギ70\%・アカマッ $30 \%$ ）で加重平 均し21.1 GJ/t を求め, さらに, 湿量基準 (乾量基準)
の含水率30\% (43\%), 水素含有率（全乾時） $6 \%{ }^{24)}$ を用いて，低位発熱量計算式 ${ }^{25)}$ により $13.1 \mathrm{GJ} / \mathrm{t}$ を 得た。これらの算定の結果, 熱供給量当たりの LPG 代替量（SL）は $12.6 \mathrm{~m}^{3} / \mathrm{GJ}$-heat となった。

この熱供給量当たりの LPG 代替量 $\left(\mathrm{m}^{3} / \mathrm{GJ}\right.$ heat）にLPG 消費に伴う GHG 排出量原単位（kg$\mathrm{CO}_{2 \text {-eq }} / \mathrm{m}^{3}$ ) (Table 2) を乗じることにより, LPG 代替に伴う $\mathrm{GHG}$ 排出削減量として92.4 kg- $\mathrm{CO}_{2 \text {-eq }}$ / GJ-heatを算出した。

\section{3. 結 果}

木質バイオマス地域熱供給システムのライフサイ クル GHG 排出量・削減量の評価結果を Table 4 に 示した。丸太生産過程から熱供給過程までの GHG 排出量は70.8 $\mathrm{kg}-\mathrm{CO}_{2-\mathrm{eq}} / \mathrm{GJ}$-heat となった。各 $\mathrm{GHG}$ の排出割合は $\mathrm{CO}_{2}$ 由来が $96 \%$ で大部分を占め, $\mathrm{CH}_{4}$ 由来は $2 \%, \mathrm{~N}_{2} \mathrm{O}$ 由来は $2 \%$ であった。各ライフサ イクル過程の排出割合を Fig. 4 に示した。熱供給過 程からの排出量が全体の $92 \%$ を占め, 特に電力由 来の排出量が $69 \%$ で最も大きく, LPG 由来が $16 \%$, 灯油由来が $7 \%$ と続き, チップ抢よび工業用水由 来はともに $1 \%$ 未満であった。また, 丸太生産過 程からの排出量は全体の $3 \%$, 丸太輸送過程および チップ生産過程はともに $2 \%$, チップ輸送過程は 1 \%となった。一方, 被代替過程による LPG 代替に 伴う GHG 排出削減量は92.4 kg- $\mathrm{CO}_{2 \text {-eq }} / \mathrm{GJ}$-heat で あり, これを考慮した正味の GHG 排出量は一 $21.6 \mathrm{~kg}-\mathrm{CO}_{2-\mathrm{eq}} / \mathrm{GJ}$-heat となり, 化石燃料代替に伴 う削減効果があることが分かった。

Table 4. Evaluation result for life cycle greenhouse gas (GHG) emissions and reductions (+ : emissions, - : reductions).

\begin{tabular}{|l|l|r|}
\hline \multicolumn{2}{|c|}{ Life cycle process } & \multicolumn{1}{c|}{ Vnit: $\mathrm{kg}-\mathrm{CO}_{2 \text {-eq }} / \mathrm{GJ}$-heat } \\
\hline \hline \multirow{3}{*}{ Log production process } & 1.0 \\
& Gasoline consumption & 0.8 \\
& Lubricant consumption & 1.0 \\
\hline Log transport process & Light oil consumption & 1.1 \\
\hline Chip production process & Light oil consumption & 1.5 \\
\hline Chip transport process & Light oil consumption & 0.8 \\
\hline \multirow{4}{*}{ Heating process } & Chip consumption & 0.003 \\
& LPG consumption & 11.2 \\
& Kerosene consumption & 4.6 \\
& Electricity consumption & 48.8 \\
Substituted process & Industrial water consumption & 0.03 \\
\hline \multirow{2}{*}{ Total } & LPG substitution & -92.4 \\
\hline & Emissions (log production to heating) & 70.8 \\
\cline { 2 - 3 } & Net emissions (log production to substituted) & -21.6 \\
\hline
\end{tabular}




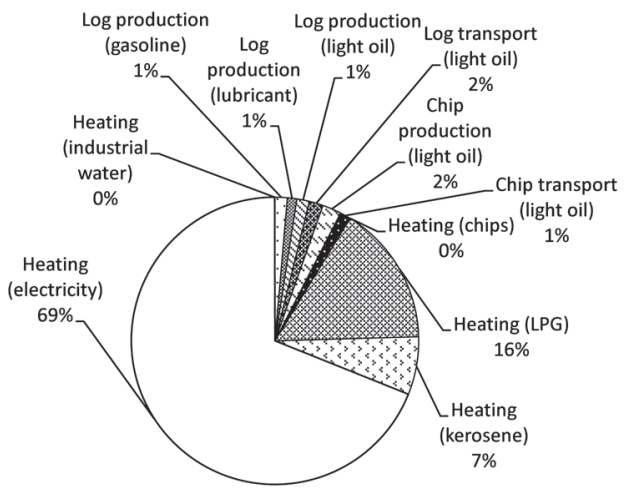

Fig. 4. Breakdown of greenhouse gas (GHG) emissions (from the log production process to the heating process).

\section{4. 考察}

\section{1 先行研究との比較}

本研究結果と先行研究との比較を行った。1.にお いて述べたと拈り，日本に扔ける木質バイオマスの 地域熱供給を対象とした先行研究はこれまで報告さ れていないため, 木材乾燥熱, 発電, 木質ペレット を対象とした先行研究 ${ }^{5,11)}$ との比較を行うこととし た。ただし，本研究と先行研究では，木質バイオマ スの種類, システム境界, GHG 排出量原単位, 地 球温暖化係数等が全て統一されているわけではない ことに留意する必要がある。古俣ら ${ }^{5)}$ は林地残材の 発電利用に打けるライフサイクル GHG 排出量を評 価している。林地残材の種類，ボイラー形式，発電 効率の違いにより, 受電端電力量当たりの GHG 排 出量は0.10 1.27 kg-CO 2 -eq $/ \mathrm{kWh}$ の範囲で幅が生じ ると報告している。本研究の結果に扔ける熱供給量 の単位を GJ から $\mathrm{kWh}(1 \mathrm{kWh}=0.0036 \mathrm{GJ})$ に換 算すると, 丸太生産過程から熱供給過程までの GHG 排出量は $0.25 \mathrm{~kg}-\mathrm{CO}_{2-\mathrm{eq}} / \mathrm{kWh}$-heat となり, 発 電よりも GHG 排出量が小さくなる場合もあれば大 きくなる場合もあることが分かった。海外の先行研 究3, 14) では, 熱供給は発電よりもライフサイクル GHG 排出量が大幅に小さいことが報告されており, 熱供給の $\mathrm{GHG}$ 排出量は発電の $30 \%$ 程度 ${ }^{3)}$ とされて いる。一方, 本研究対象の地域熱供給は発電と比較 して GHG 排出量が大幅に小さいという状況には至 っていないと考えられる。また，一重・服部 ${ }^{11)} は$ 製材残材による製材乾燥熱, 発電, ペレット利用を 対象としたライフサイクル GHG 排出量および化石 燃料代替による GHG 排出削減量を検討している。 製材残材利用量当たりの正味（被代替過程を含む）
の GHG 排出量は製材乾燥熱で-380〜 - $280 \mathrm{~kg}-$ $\mathrm{CO}_{2-\mathrm{eq}} / \mathrm{m}^{3}$, 発電で-79〜 $28 \mathrm{~kg}-\mathrm{CO}_{2 \text {-eq }} / \mathrm{m}^{3}$, ペレッ トで $-302 \sim-13 \mathrm{~kg}-\mathrm{CO}_{2-\mathrm{eq}} / \mathrm{m}^{3}$ の範囲となることを 報告している。本研究の結果に扔ける熱供給量をチ ップ消費量（1.0 $\mathrm{m}^{3} / \mathrm{GJ}$-heat）（Table 1）に換算す ると, チップ消費量当たりの正味（被代替過程を含 む）の $\mathrm{GHG}$ 排出量は $-21 \mathrm{~kg}-\mathrm{CO}_{2-\mathrm{eq}} / \mathrm{m}^{3}$ となった。 これらの結果から, 本研究対象の地域熱供給は製材 乾燥熱よりも GHG 排出削減効果が小さくなる可能 性が高いが，発電やペレットとは削減効果が競合す る状況にあると考えられる。

\section{2 感度分析}

本研究では，主に聞き取り調査によって評価に用 いたデー夕（Table 1）を収集したため，3.におい て示した結果（Table 4) にはデー夕の不確実性が 含まれている。そこで, 不確実性が大きいと考えら れる項目について感度分析を行い, 結果への影響を 考察することとした。丸太からのチップ生産量, チ ップの容積密度, チップの高位発熱量, 丸太の含水 率，チップの含水率を分析対象とした。丸太からの チップ生産量については, A 社への聞き取り調査 で得られたチップ生産量の変動状況を踏まえて, Table 1 において仮定した值である $3 \mathrm{~m}^{3}$ - chip $/ \mathrm{m}^{3}$ $\log$ が2.8 3.2 $\mathrm{m}^{3}$ - chip $/ \mathrm{m}^{3}-\log$ の範囲で変動するこ とを想定した。チップの容積密度については, Table 1に打いて仮定した $0.25 \mathrm{t} / \mathrm{m}^{3} か ゙ 0.2 \sim 0.3 \mathrm{t} / \mathrm{m}^{3}$ の範囲で変動することを検討した。チップの高位発 熱量は, $\mathrm{B}$ 社への聞き取り調査を踏まえ, スギとア カマツの樹種比率が $\pm 20 \%$ 変化することにより,

Table 1 において仮定した21.1 GJ/t (全乾時) が20.9 〜 $21.3 \mathrm{GJ} / \mathrm{t}$ の範囲で変動すると想定した。丸太の含 水率は, Table 1 に扔ける50\%（湿量基準）が40〜 $60 \%$ の範囲で変動するとした。チップの含水率につ いては，B社への聞き取り調査により，Table 1 に おける30\%（湿量基準）が14４4\% の範囲で変動す ることを検討した。

感度分析の結果を Table 5 に示した。丸太からの チップ生産量において, 正味の GHG 排出量は一 $21.3 \sim-22.0 \mathrm{~kg}-\mathrm{CO}_{2 \text {-eq }} / \mathrm{GJ}$-heat となり，3.におい て示した正味の $\mathrm{GHG}$ 排出量の 98 ～102\% に相当し た。チップの容積密度では, 正味の GHG 排出量は $-20.3 \sim-22.5 \mathrm{~kg}-\mathrm{CO}_{2 \text {-eq }} / \mathrm{GJ}$-heat となり，3.にお いて示した正味の GHG 排出量の 94 104\%の範囲 であった。チップの高位発熱量については, 正味の GHG 排出量は-21.6〜 - $21.7 \mathrm{~kg}-\mathrm{CO}_{2 \text {-eq }} / \mathrm{GJ}$-heat と なり，3.に扔ける結果からほぼ変化しなかった。丸 太の含水率扔よびチップの含水率に扔いては，正味 
の $\mathrm{GHG}$ 排出量は-21.4〜 - 21.8 kg- $\mathrm{CO}_{2-\mathrm{eq}} / \mathrm{GJ}$-heat およびー20.5〜 - 22.4 kg-CO $\mathrm{CO}_{2-\mathrm{eq}} / \mathrm{GJ}$-heat となり， 3.における結果の99〜101\%および95〜104\%の範 囲であった。これらの結果から，数值の不確実性を 考慮しても正味の GHG 排出量に大きな影響はなく, GHG 排出削減効果は得られると考えられる。

\section{3 さらなる $\mathrm{GHG}$ 排出削減の可能性}

3.で示した結果（Table 4）において，熱供給過 程および被代替過程における GHG 排出量・削減量 がライフサイクル全体の大部分を占めていたことか ら,これらの過程における熱利用効率および代替す る化石燃料の種類に着目し，さらなる $\mathrm{GHG}$ 排出削 減の可能性を検討した。熱利用効率については, 現
状の $29 \%$ が変化（エネルギー投入量に対するエネ ルギー産出量が増減）することを検討した。熱利用 効率の変化に対する正味の GHG 排出量の分析結果 を Fig. 5に示した。熱利用効率を75\%まで改善する ことができると, 正味の GHG 排出量は- $65.3 \mathrm{~kg}-$ $\mathrm{CO}_{2 \text {-eq }} / \mathrm{GJ}$-heatとなり, 現状の 3 倍に GHG 排出削 減効果が大きくなった。一方, 熱利用効率が $23 \%$ を 下回ると，正味の GHG 排出量は正の值となり削減 効果はなくなることが分かった。代替する化石然料 の種類については, 現状の LPGに対して灯油およ び重油を想定した。式（1）・（2）と同様の方法によ り熱供給量当たりの灯油および重油代替量（L/GJheat）を求め, 灯油および重油の消費に伴う GHG

Table 5. Results of sensitivity analysis ( + : emissions, - : reductions).

\begin{tabular}{|c|c|c|c|c|c|c|c|}
\hline & \multirow{2}{*}{ Life cycle process } & \multicolumn{2}{|c|}{$\begin{array}{l}\text { Chip produc- } \\
\text { tion volume } \\
\text { from logs }\end{array}$} & \multicolumn{2}{|c|}{$\begin{array}{l}\text { Density of } \\
\text { chips }\end{array}$} & \multicolumn{2}{|c|}{$\begin{array}{l}\text { Gross calorific } \\
\text { value of chips }\end{array}$} \\
\hline & & \begin{tabular}{|c|}
2.8 \\
$\mathrm{~m}^{3} / \mathrm{m}^{3}$ \\
\end{tabular} & \begin{tabular}{c|}
3.2 \\
$\mathrm{~m}^{3} / \mathrm{m}^{3}$ \\
\end{tabular} & $\begin{array}{l}0.2 \\
\mathrm{t} / \mathrm{m}^{3} \\
\end{array}$ & $\begin{array}{c}0.3 \\
\mathrm{t} / \mathrm{m}^{3} \\
\end{array}$ & $\begin{array}{l}20.9 \\
\mathrm{GJ} / \mathrm{t}\end{array}$ & $\begin{array}{l}21.3 \\
\mathrm{GJ} / \mathrm{t}\end{array}$ \\
\hline Log production process & $\begin{array}{l}\text { Gasoline consumption } \\
\text { Lubricant consumption } \\
\text { Light oil consumption }\end{array}$ & $\begin{array}{l}1.0 \\
0.8 \\
1.1\end{array}$ & $\begin{array}{l}0.9 \\
0.7 \\
0.9\end{array}$ & $\begin{array}{l}1.2 \\
0.9 \\
1.3\end{array}$ & $\begin{array}{l}0.8 \\
0.6 \\
0.8\end{array}$ & $\begin{array}{l}1.0 \\
0.8 \\
1.0\end{array}$ & $\begin{array}{l}1.0 \\
0.8 \\
1.0\end{array}$ \\
\hline Log transport process & Light oil consumption & 1.2 & 1.0 & 1.4 & 0.9 & 1.1 & 1.1 \\
\hline Chip production process & Light oil consumption & 1.6 & 1.4 & 1.9 & 1.3 & 1.5 & 1.5 \\
\hline Chip transport process & Light oil consumption & 0.8 & 0.8 & 0.8 & 0.8 & 0.8 & 0.8 \\
\hline Heating process & $\begin{array}{l}\text { Chip consumption } \\
\text { LPG consumption } \\
\text { Kerosene consumption } \\
\text { Electricity consumption } \\
\text { Industrial water consumption }\end{array}$ & $\begin{array}{r}0.003 \\
11.2 \\
4.6 \\
48.8 \\
0.03\end{array}$ & $\begin{array}{r}0.003 \\
11.2 \\
4.6 \\
48.8 \\
0.03\end{array}$ & $\begin{array}{r}0.003 \\
11.2 \\
4.6 \\
48.8 \\
0.03\end{array}$ & $\begin{array}{r}0.002 \\
11.2 \\
4.6 \\
48.8 \\
0.03\end{array}$ & $\begin{array}{r}0.003 \\
11.2 \\
4.6 \\
48.8 \\
0.03\end{array}$ & $\begin{array}{r}0.003 \\
11.2 \\
4.6 \\
48.8 \\
0.03\end{array}$ \\
\hline Substituted process & LPG substitution & -92.4 & -92.4 & -92.4 & -92.4 & -92.4 & -92.4 \\
\hline \multirow{2}{*}{ Total } & Emissions (log production to heating) & 71.2 & 70.4 & 72.1 & 69.9 & 70.8 & 70.8 \\
\hline & Net emissions (log production to substituted) & -21.3 & -22.0 & -20.3 & -22.5 & -21.6 & -21.7 \\
\hline
\end{tabular}

Table 5. (continued) Results of sensitivity analysis (+ : emissions, - : reductions).

Unit: $\mathrm{kg}-\mathrm{CO}_{2-\mathrm{eq}} / \mathrm{GJ}$-heat

\begin{tabular}{|c|c|c|c|c|c|}
\hline & \multirow[t]{2}{*}{ Life cycle process } & \multicolumn{2}{|c|}{$\begin{array}{l}\text { Moisture content } \\
\text { of logs }\end{array}$} & \multicolumn{2}{|c|}{$\begin{array}{l}\text { Moisture content } \\
\text { of chips }\end{array}$} \\
\hline & & $40 \%$ & $60 \%$ & $14 \%$ & $44 \%$ \\
\hline Log production process & $\begin{array}{l}\text { Gasoline consumption } \\
\text { Lubricant consumption } \\
\text { Light oil consumption }\end{array}$ & $\begin{array}{l}1.0 \\
0.8 \\
1.0\end{array}$ & $\begin{array}{l}1.0 \\
0.8 \\
1.0\end{array}$ & $\begin{array}{l}1.0 \\
0.8 \\
1.0\end{array}$ & $\begin{array}{l}1.0 \\
0.8 \\
1.0\end{array}$ \\
\hline Log transport process & Light oil consumption & 0.9 & 1.4 & 1.1 & 1.1 \\
\hline Chip production process & Light oil consumption & 1.5 & 1.5 & 1.5 & 1.5 \\
\hline Chip transport process & Light oil consumption & 0.8 & 0.8 & 0.8 & 0.8 \\
\hline Heating process & $\begin{array}{l}\text { Chip consumption } \\
\text { LPG consumption } \\
\text { Kerosene consumption } \\
\text { Electricity consumption } \\
\text { Industrial water consumption }\end{array}$ & $\begin{array}{r}0.003 \\
11.2 \\
4.6 \\
48.8 \\
0.03 \\
\end{array}$ & $\begin{array}{r}0.003 \\
11.2 \\
4.6 \\
48.8 \\
0.03 \\
\end{array}$ & $\begin{array}{r}0.003 \\
11.2 \\
4.6 \\
48.8 \\
0.03 \\
\end{array}$ & $\begin{array}{r}0.003 \\
11.2 \\
4.6 \\
48.8 \\
0.03 \\
\end{array}$ \\
\hline Substituted process & LPG substitution & -92.4 & -92.4 & -93.2 & -91.3 \\
\hline & Emissions (log production to heating) & 70.6 & 71.0 & 70.8 & 70.8 \\
\hline $10 t a l$ & Net emissions (log production to substituted) & -21.8 & -21.4 & -22.4 & -20.5 \\
\hline
\end{tabular}


排出量原単位 $\left(\mathrm{kg}-\mathrm{CO}_{2-\mathrm{eq}} / \mathrm{L}\right.$ ) (Table 2) を各々乗じ, 灯油抒よび重油代替に伴う GHG 排出削減量 $(\mathrm{kg}$ $\mathrm{CO}_{\text {-eq }} / \mathrm{GJ}$-heat）を算定した。なお，式（2）におけ る灯油および重油の低位発熱量 (GJ-kerosene/L,

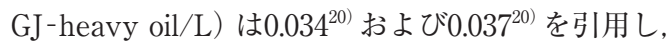
熱利用効率は LPG と同值の84\%（Table 1）を用い ることとした。各化石燃料の被代替過程における GHG 排出削減量および正味の GHG 排出量の分析結 果を Fig. 6 に示した。灯油あるいは重油との代替を 想定すると, 現状の LPGよりも化石燃料代替に伴 う GHG 排出削減量は大きくなることが分かった。 正味の $\mathrm{GHG}$ 排出量において, 灯油では- $23.1 \mathrm{~kg}-$ $\mathrm{CO}_{2 \text {-eq }} / \mathrm{GJ}$-heat, 重油では- $25.7 \mathrm{~kg}$ - $\mathrm{CO}_{2 \text {-eq }} / \mathrm{GJ}$ heat の削減効果が期待できる結果となった。ただ し, 上述の熱利用効率と比較して結果へ与える影響 は小さかった。

\section{5. 結 論}

本研究では, 木質バイオマス地域熱供給システム

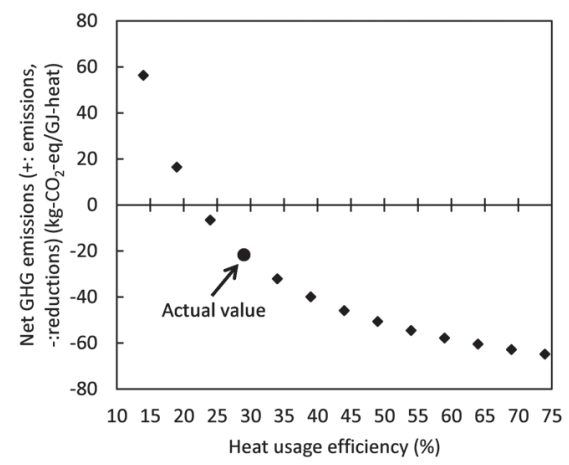

Fig. 5. Heat usage efficiency and net greenhouse gas (GHG) emissions of the district heating and cooling (DHC) system.

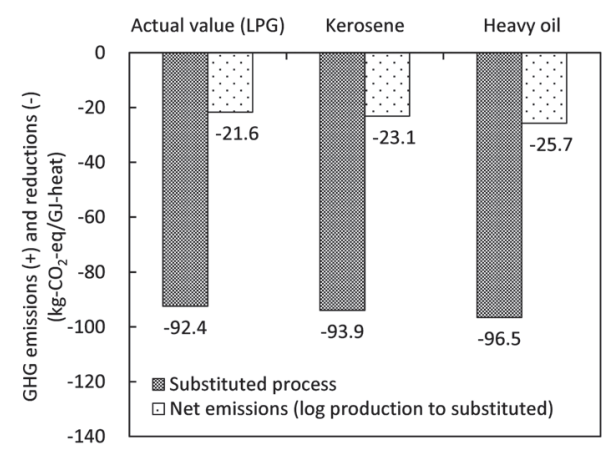

Fig. 6. The substituted fossil fuels and net greenhouse gas (GHG) emissions of the district heating and cooling (DHC) system.
の先進事例地域である岩手県紫波町を対象に, ライ フサイクル GHG 排出量・削減量を評価した。得ら れた主な知見は以下のとおりである。

1. 丸太生産過程から熱供給過程までのライフサイ クル GHG 排出量は70.8 kg-CO $\mathrm{CO}_{2 \text {-eq }} / \mathrm{GJ}$-heat とな り，熱供給過程からの排出量が全体の約 $92 \%$ を占 め, 特に電力由来の排出量が大きい。一方, 被代 替過程において $92.4 \mathrm{~kg}-\mathrm{CO}_{2-\mathrm{eq}} / \mathrm{GJ}$-heat の GHG 排 出削減量が得られ，これを考慮した正味の GHG 排出量は-21.6 kg- $\mathrm{CO}_{2 \text {-eq }} / \mathrm{GJ}$-heat となり, 化石 燃料代替に伴う $\mathrm{GHG}$ 排出削減効果が期待できる。

2. 複数のエネルギー利用形態を対象とした先行研 究と比較した結果, 本研究対象の地域熱供給に求 けるライフサイクル GHG 排出量・削減量は木材 乾燥熱, 発電, 木質ペレットと比べて優位とはい えない。

3. 感度分析の結果, 丸太からのチップ生産量, チ ップの容積密度, チップの高位発熱量, 丸太の含 水率, チップの含水率に扔けるデー夕の不確実性 を考慮しても, 評価結果への影響は大きくなく, GHG 排出削減効果は得られる。

4. 熱利用効率が $23 \%$ を下回ると正味の GHG 排出 量が正の值となり， GHG 排出削減効果は得られ なくなる。一方, 熱利用効率を $75 \%$ まで改善す ることができれば, 現状の 3 倍の GHG 排出削減 効果が期待できる。

5. 代替する化石燃料として灯油や重油を想定する と, 現状の LPG と比べて GHG 排出削減効果が 大きくなる。ただし, 熱利用効率の変化と比較す ると結果への影響は小さい。

本研究で対象とした木質バイオマス地域熱供給シ ステムは現状に打いて熱需要が十分でなく, 熱利用 効率は高くなかった。今後町役場庁舎や一般住宅に おいて安定した熱需要が確保できれば, 熱利用効率 が向上し GHG 排出削滅効果も増加すると考えられ, 今後の継続的なモニタリングが重要である。また, 他の地域に扔ける木質バイオマス地域熱供給システ ムの LCA を実施し, 本研究結果との比較拈よび日 本全体における知見を蓄積することも今後の主要課 題である。

\section{謝辞}

本研究を行うにあたり， A 社および $\mathrm{B}$ 社の方々 に多大なご協力を頂きました。ここに記して謝意を 表します。本研究は, 環境省第且期「環境経済の政 策研究」および科研費15H02863の支援により行わ れました。 


\section{文献}

1) Intergovernmental Panel on Climate Change (IPCC) : Climate Change 2014. Fifth Assessment Report, Mitigation of Climate Change, Cambridge University Press, New York, 2014.

2）資源エネルギー庁 : 再生可能エネルギーの固 定価格買取制度ガイドブック. 資源エネルギ 一庁, 東京, 2015.

3) Manomet Center for Conservation Sciences: Biomass sustainability and carbon policy study. NCI-2010-03, Manomet Center for Conservation Sciences, Massachusetts, 2010.

4）森のエネルギー研究所：木質バイオマス人材 育成事業実施報告書, 森のエネルギー研究所, 東京, 2012 .

5）古俣寛隆, 酒井明香, 八坂通泰, 石川佳生, 服部 順昭：林地残材を用いた発電のライフサイク ルアセスメント 一温室効果ガス排出量の削減 に関する一考察一. 木材学会誌 59(1), 22-28 (2013).

6）古俣寛隆, 折橋 健, 石川佳生,一重喬一郎, 服 部順昭：北海道産木質ペレットのライフサイ クルアセスメントによる環境影響評価. 木材 学会誌 56(3), 139-148 (2010).

7）石坂和明, 村山克己, 伊坪徳宏 : ペレットスト ーブのライフサイクル環境影響評価. 日本 LCA学会誌 3(1), 45-51 (2007).

8) Higo, M., Dowaki, K.: A Life Cycle Analysis on a Bio-DME production system considering the species of biomass feedstock in Japan and Papua New Guinea. Appl. Energy 87, 5867 (2010).

9) Sunde, K., Brekke, A., Solberg, B. : Environmental impacts and costs of woody Biomass-to-Liquid (BTL) production and use - A review. For. Policy Econ. 13, 591602 (2011).

10) Pucker, J., Zwart, R., Jungmeier, G. : Greenhouse gas and energy analysis of substitute natural gas from biomass for space heat. Biomass Bioenergy 38, 95-101 (2012).

11）一重喬一郎, 服部順昭：製材残材のエネルギー 利用における温室効果ガス排出量の評価. 木 材学会誌 57(2), 63-71 (2011).

12) Bram, S., De Ruyck, J., Lavric, D.: Using biomass: A system perturbation analysis. Appl. Energy 86, 194-201 (2009).

13) Kayo, C., Aramaki, T., Hanaki, K.: Effect of change of forest carbon storage on net carbon dioxide balance of wood use for energy in Japan. J. Ind. Ecol. 15(1), 122-136 (2011).

14) Puettmann, M. E., Lippke, B.: Woody biomass substitution for thermal energy at softwood lumber mills in the US Inland Northwest. For. Prod. J. 62 (4), 273-279 (2012).

15）紫波町：紫波町暮らしのガイドブック, 紫波町 役場, 紫波町, 2015.

16）紫波グリーンエネルギー：紫波中央駅前エネ ルギーステーション事業紹介資料, 紫波グリ ーンエネルギー，紫波町, 2015.

17）森林総合研究所：木材工業ハンドブック改訂 3 版, 丸善, 東京, 1982, p. 103.

18）日本国：京都議定書 3 条 3 及び 4 の下での LULUCF活動の補足情報に関する報告書, 日 本政府, 東京, 2009 .

19）岩岡正博, 一二三雅透：木材生産作業のエネル ギー消費と二酸化炭素排出量 (後編). 機械化 林業 655(6), 1-6 (2008).

20）戒能一成：エネルギー源別標準発熱量・炭素 排出係数の改訂案について, 2013年度改訂標 準発熱量・炭素排出係数表, 経済産業研究所, 東京, 2014.

21）産業環境管理協会：MiLCAデータベース, 産 業環境管理協会, 東京, 2014.

22) The International Organization for Standardization (ISO) : Greenhouse gases Carbon footprint of products - Requirements and guidelines for quantification and communication, The International Organization for Standardization, Geneva, 2013, p. 52.

23) Intergovernmental Panel on Climate Change (IPCC) : Climate Change 2013, Fifth Assessment Report, The Physical Science Basis, Cambridge University Press, New York, 2013.

24) Abe, F.: Calorific value of Japanese coniferous wood. Bull. For. For. Prod. Res. Inst. 338, 91-100 (1986).

25）森林総合研究所：木材工業ハンドブック改訂 4 版, 丸善, 東京, 2004, p. 1037. 